\title{
ANALISIS KEBUTUHAN NELAYAN TERHADAP PEMBIAYAAN PERBANKAN SYARIAH DI PELABUHAN RATU SUKABUMI JAWA BARAT
}

\section{ANALYSIS OF NEEDS FISHERMAN TO FINANCING OF SHARIA BANKING IN PELABUHAN RATU SUKABUMI JAWA BARAT}

\author{
Nur Atni Fadillahª; Tuti Kurnia² \\ 1aProgram Studi Perbankan Syariah Fakultas Ekonomi Islam Universitas Djuanda, Jl. Tol \\ Ciawi No. 1, Kotak Pos 35 Bogor 16720, e-mail: atnifadillah79@gmail.com \\ 2Program Studi Perbankan Syariah Fakultas Ekonomi Islam Universitas Djuanda, Jl. Tol \\ Ciawi No. 1, Kotak Pos 35 Bogor 16720
}

\begin{abstract}
The purpose of this study was to determine the condition of fishing economy of coastal areas Pelabuhan Ratu Beach Sukabumi, West Java including into condition of economic is prosperous or less prosperous, and analyzing financial products such as what is appropriate to meet the needs of fishermen, from daily necessities to the need to go to sea, The method used in this research is descriptive qualitative method. conclusions of this study is the economic condition of fishermen Pelabuhan Ratu still relatively less prosperous and have not been able to meet their needs, either daily needs as well as the need to go to sea. Islamic bank financing products accordingly to meet the financing needs of fishermen is using the murabaha contract.
\end{abstract}

Keywords: Financing, Fisherman, Supplies

\begin{abstract}
ABSTRAK
Penelitian ini bertujuan untuk mengkaji sistem perekonomian nelayan kawasan pesisir Pantai Pelabuhan Ratu Sukabumi Jawa Barat termasuk sejahtera atau kurang sejahtera, serta menganalisis produk pembiayaan untuk nelayan, dari kebutuhan sehari-hari sampai kebutuhan untuk melaut. metode deskriptif kualitatif adalah Metode dari penelitian ini. Kesimpulan penelitian ini adalah, kondisi perekonomian nelayan Pelabuhan Ratu masih tergolong kurang sejahtera. akad murabahah bil kafalah adalah produk pembiayaan yang sesuai untuk nelayan
\end{abstract}

Kata Kunci : Kebutuhan, Nelayan, Pembiayaan

Fadillah Atni. 2017. Analisis Kebutuhan Nelayan Terhadap Pembiayaan Perbankan Syariah di Pelabuhan Ratu Sukabumi Jawa Barat. Jurnal Nisbah 4 (2): 157-170. 


\section{PENDAHULUAN}

Jawa Barat masuk ke dalam tiga provinsi di Indonesia yang memberikan berkontribusi terhadap sektor perikanan. Jumlah nelayan di Jawa Barat saat ini mencapai 183.000 nelayan (Kemenristek, 2016) jumlah ini masih jauh sedikit bila dibandingkan dengan nelayan di Lamongan Jawa Timur yang jumlah nelayannya sebanyak 28.000 nelayan (Wardono, 2015:4).

Jumlah nelayan yang masih sedikit bukan menjadi penghalang karena status nelayan sudah menjadi armada perikanan. Armada perikanan adalah organisasi kelompok kapal yang mencari ikan bersama-sama di suatu perairan.

Selain menjadi armada ada sebab lain mengapa penelitian ini dilakukan diantaranya yaitu, kebutuhan nelayan di wilayah ini sudah dipenuhi yaitu seperti sarana dan prasarananya, penyediaan barang logistik maupun kebutuhan operasionalnya. Sistem pelayanan terhadap kapal kecil juga sudah tertulis di lembaga yang menangani khusus tentang perikanan.

Akan tetapi kehidupan para nelayan tersebut kurang sejahtera, ada lima factor yang hal tersebut terjadi , pertama, adalah adanya kesenjangan antara nelayan, yang kedua, karena keterbatasan alat tangkap, yang ketiga karena keterbatasan wilayah tangkap,keempat,karena faktor cuaca dan musim, dan yang kelima karena perilaku konsumtif nelayan.

Dari uraian permasalahan kehidupan nelayan tadi, inti dari permasalahan adalah terkait dengan pola kebutuhan hidup nelayan seharihari. Ada dua Kebutuhan nelayan, kebutuhan primer merupakan kebutuhan utama. Sedangkan kebutuhan sekunder merupakan kebutuhan yang bisa dipenuhi ketika kebutuhan primernya sudah terpenuhi (Dewi Rosalia, 2016:1).
Kebutuhan primer nelayan mencakup kebutuhan pokok seperti kebutuhan akan konsumsi sandang pangan dan papan, ada tiga bagian kebutuhan sekunder nelayan.

Pertama, kebutuhan akan alat transportasi untuk melaut, yang kedua adalah kebutuhan alat tangkap dan yang ketiga yaitu kebutuhan untuk pemeliharaan alat. Masih banyak nelayan Indonesia yang memilih meminjam ke rentenir dan belum terlepas dari kemiskinan dan hutang.

Potongan bunga rentenir bisa mencapai $20-40 \%$ melebihi pendapatan mereka sehari-hari. Tercatat data nelayan miskin pada di tahun 2013 ada 7,87 juta orang (Syafrini, 2014:67). Mereka membutuhkan alternatif lain selain meminjam kepada rentenir, alternatif yang justru tidak menambah beban hidup mereka menjadi lebih berat tetapi meringankan.

Bank syariah menjadi alternatif dan solusi untuk mengurangi permasalahan terkait dengan kebutuhan hidup para nelayan.

Bank syariah menggunakan prinsip bagi hasil dan berbagi risiko dalam kegiatan pembiayaanya dan menggunakan model pembiayaan muamalah maaliyah (Sari, 2016:1). Pembiayaan juga hendaknya diarahkan kepada golongan ekonomi lemah, sehingga usaha dan pendapatan mereka menjadi lebih meningkat (Umam, 2013:211).

Akan tetapi kurangnya sosialisasi mengenai program pemerintah tersebut masih kurang dan nelayan belum mampu melunasi pembiayaan yang mereka ajukan. Maka dari itu pembiayaan tersebut bisa sesuai untuk nelayan atau justru sebaliknya, Untuk itu penulis tertarik menjadikan permasalahan tersebut ke dalam penelitian. 


\section{MATERI DAN METODE}

\section{Nelayan}

Nelayan dikategorikan dalam dua kelompok, nelayan kecil dan nelayan tradisional. Nelayan kapal kecil merupakan nelayan yang memakai kapal berukuran kecil (Sugiyarto, 2016:13). Jumlah awak kapal nelayan kecil sekitar 2-5orang (Moelyaningrum, 2016:3). Biasanya hasil tangkapannya tidak terlalu banyak karena kapasitas kapalnya dibawah kapal nelayan besar karena kondisi kapalyang kecil. (Iflakhah, 2016:10).

Nelayan tradisional merupakan nelayan yang menjalankan profesi nelayan turun temurun. Nelayan tradisional melaut dengan mengandalkan peralatan seadanya dengan hasil tangkapan tidak menentu (Dariwu, 2016:3). Nelayan tradisional menangkap ikan tanpa menggunakan bantuan teknologi, dukungan modal dan lembaga usaha yang mendukung (Handajani, 2015:1). Nelayan tradisional menggantungkan hidup sehari-harinya terhadap jumlah hasil tangkapan dan dalam jumlah sederhana (Sulaiman,2014:33).

Nelayan tradisional diartikan secara umum merupakan nelayan yang menangkap ikan dengan alat pancing tradisional dan lingkup atau wilayah penangkapan masih terbatas. Nelayan tradisional bekerja hanya untuk memperbaiki kehidupannya bukan untuk dijadikan potensi usaha (Rangkuti, 2013:186).

\section{Karakteristik Nelayan}

a. Usia Nelayan

Usia produktif nelayan adalah usia yang masih aktifdalam menangkap ikan dan menghasilkan pendapatan (Yampu, 2015:52). Batas usia untuk nelayan laut lepas dan sepanjang pantai adalah usia 50 tahun ke atas.

\section{b. Pendapatan Rumah Tangga Nelayan}

Pendapatan adalah faktor penentu bagi peningkatan kesejahteraan nelayan sehingga nelayan dapat mengatur pola konsumsi setiap harinya. Pendapatan nelayan tersebut bisa dihasilkan dari jumlah tangkapan dan kegiatan lain selain menangkap ikan (Kalsum, 2014:71). Ada dua jenis pendapatan nelayan, yaitu:

1) Pendapatan nelayan adalah seluruh pendapatan bersih dari selisih antara seluruh pendapatan usaha melaut dari produksi pengolahan ikan selama satu bulan dan dinyatakan dalam rupiah.

2) Pendapatan total nelayan adalah seluruh penghasilan nelayan dari semua sumber pendapatan, baik bekerja sebagai nelayan, atau bukan sebagai nelayan, akan tetapi sebagai petani, pedagang dan buruh yang dinyatakan dalam jumlah rupiah (Kurniasari, 2016:36). Pendapatan nelayan terkadang tidak menentu. Sedangkan kebutuhan mereka sangatlah banyak, terutama untuk kebutuhan melaut. Pendapatan nelayan tidak hanya diperoleh dari menangkap ikan saja. Pekerjaan sampingan saat musim paceklik datang atau musim tangkap ikan sedang menurun membuat pekerjaan sampingan ini dapat membantu nelayan untuk menambah penghasilannya (Oktofriyadi, 2014: 77-78). Pendapatan utama sebagai nelayan lebih kecil dibandingkan pekerjaan sampingan (Ardhan, 2015:57).

c. Pengeluaran Rumah Tangga Nelayan

Pengeluaran pangan biasanya dikeluarkan untuk kebutuhan sehari-hari contohnya, untuk kebutuhan membeli sayuran, buah-buahan, makanan dan minuman, sedangkan untuk pengeluaran non-pangan adalah pengeluaran untuk rumah tinggal, pakaian, penutup kepala 
atau caping dan alas kaki atau sendal (Maulana Firdaus 2013).

d. Tingkat Pendidikan Nelayan

Tingkat pendidikan nelayan secara umum tergolong rendah, karena nelayan hanya mencapai pendidikan sampai Sekolah Dasar.

e. Jumlah Tanggungan Keluarga Nelayan

Jumlah tanggungan keluarga adalah karakteristik paling penting karena berpengaruh pada pola konsumsi. Biasanya keluarga nelayan berkisar 3-5 orang dimulai dari ayah, ibu dan 3 orang anak, lebih banyak ketimbang rata-rata ukuran jumlah keluarga pada umumnya yaitu sebanyak 4 orang (Yusuf, 2016:4).

\section{Tingkat Kesejahteraan Nelayan}

Kesejahteraan terbagi dua, yang pertama yaitu, kesejahteraan subjektif adalah kesejahteraan yang langsung dirasakan oleh nelayan dan mencakup kedalam tiga dimensi, ekonomi, sosial dan psikologis. Kesejahteraan objektif adalah kesejahteraan yang dilihat dari kriteria kehidupan nelayan (Widyaningsih, 2015: 186-187)

\section{Kebutuhan Nelayan}

Kebutuhan nelayan tidak sedikit dalam menunjang kegiatan mereka untuk melaut setiap harinya kebutuhan akan solar, alat tangkap, kebutuhan untuk pemeliharaan alat untuk melaut dan kebutuhan sehari-sehari seperti sandang, pangan dan papan. Kebutuhan nelayan yang paling utama adalah kebutuhan untuk melaut. Kebutuhan utama bagi nelayan adalah solar. Terutama nelayan kapal tangkap yang besar.

Kebutuhan nelayan bukan hanya pada untuk melaut dan pemeliharaannya saja, akan tetapi kebutuhan modal pun sama pentingnya akan tetapi menjadi nelayantidakmudah karena banyak ketidakpastian yang terjadi. Nelayan sangat membutuhkan modal tanpa adanya jaminan.

\section{Pembiayaan Bank Syariah}

Berikut gambaran produk-produk pembiayaan di Bank Syariah.

1. Al-Wadiah (simpanan atau titipan)

Al-Wadiah merupakan akad berupa penitipan barang antara dua pihak yang menitipkan dan dititipkan, dalam bentuk barang atau uang.

2. Al-Mudharabah

Akad perjanjian dua pihak yaitu, pemilik dimana pihak pertama sebagai pemilik modal dan pihak kedua sebagai pengelola modal yang memberikan modal dan pembagian hasil dibagi sesuai dengan perjanjian.

3. Musyarakah

Musyarakah merupakan perjanjian yang dilaksanakan oleh dua pihak yang sama-sama bekerja sama tersebut memberikan dananya terhadap suatu usaha dan keuntungan dan dibagi berdasarkan persetujuan kedua pihak tersebut.

4. Ijarah

Ijarah merupakan akad tentang sewa menyewa barang tertentu. Dalam perjanjian ini pemilik barang memperbolehkan orang yang di titip barangnya memanfaatkan barang tersebut dan membayar sewa sesuai kesepakatan.

5. Qardh

Qardh adalah akad pinjam meminjam yang wajib dikembalikan sesuai dengan yang dipinjam dan dikembalikan dengan cara diangsur atau sekaligus.

6. Rahn (Gadai)

Rahn adalah penyerahan barang atau harta sebagai jaminan atas seluruh hutang (Amin, 2016:503-504).

\section{Pembiayaan pada sektor Pertanian dan Perikanan}

1. Pembiayaan Muzaraah pada sektor pertanian

Muzaraah menurut bahasa adalah bentuk kata yang mengikuti wazan (pola) mufa'alah dari kata paling dasar yaitu alzar'u yang berarti al-imbat 
(menumbuhkan). Pengertian lain mengenaimuzara'ah adalah akad kerjasama mengenai pertanian yang dilakukan antara penggarap dan pemilik lahan dengan kesepakatan membagi hasil panen yang jumlahnya sudah ditentukan sebelumnya.

Akad muzara'ah berakhir ketika salah satu dari pihak yang melakukan perjanjian meninggal dunia akan tetapi lahan pertaniannya belum memasuki masa panen, penggarap wajib menyelesaikan tugasnya sampai masa panen tiba.

2. Pembiayaan pada sektor perikanan

Sektor kelautan dan perikanan adalah Subsektor dari pertanian. Pembiayaan pada sektor ini diberikan untuk pembelian kapal untuk kelompok nelayan akad istishna pararel.

Akad istishna pararel berlaku ketika bank ternyata bank tidak memenuhi barang pesanan nasabah dan melanjutkan akadnya kepada pihak pembuat barang. Akad ini terpisah dengan akad istishna sebelumnya, akad istishna diaplikasikan untuk pembiayaan rumah untuk usaha kelautan juga bisa dengan menggunakan istishna pararel lewat pembiayaan kapal besar untuk kelompok nelayan. Pelaksanaan akad ini tidak menyulitkan nasabah maupun pihak bank karena pembayaran bisa dilakukan dengan pembayaran terlebih dahulu istilah ini disebut down payment.

Akad Istishna Pararel bisa diterapkan sebagai solusi dari permasalahan yang dihadapi oleh nelayan, yaitu kecilnya kapasitas kapal yang membuat hasil tangkapan ikan menjadi lebih sedikit (Afandi, 2016).

\section{Metodologi Penelitian}

Metode penelitian ini adalah, metode deskriptif kualitatif yang memiliki tujuan untuk memberikan gambaran tentang kondisi perekonomian nelayan yang tinggal di wilayah pesisir serta kebutuhan nelayan terhadap pembiayaan untuk meningkatkan sistem perekonomiannya.

Nelayan adalah Objek Penelitian ini pesisir pantai Pelabuhan Ratu Sukabumi, 30 orang nelayan yang dibagi berdasarkan dua kategori yaitu nelayan kapal kecil dan nelayan kapal besar adalah populasi dan sampel yang ada di dalam penelitian ini

Data primer penelitian melalui proses wawancara terstrukur kepada responden, dengan menyiapkan terlebih dahulu pertanyaan tertulis yang jawabanya sudah disediakan. Yang kedua dengan menggunakan data yang bersumber dari literatur, buku laporan statistik perikanan dan jurnal skripsi atau biasa disebut dengan data sekunder

Teknik analisis data digunakan dengan cara mengaanalisis pendapatan nelayan, pengeluaran, kebutuhan akan modal, kesesuaian produk pembiayaan dan design lanjutan mengenai produk pembiayaan yang sesuai untuk kebutuhan nelayan.

\section{HASIL DAN PEMBAHASAN}

\section{Produksi Perikanan Tangkap Pelabuhan Ratu}

Penurunan produksi paling rendah dalam 5 tahun terakhir, terjadi pada tahun 2011, dan peningkatan produksi tertinggi ada pada tahun 2014. Berikut gambaran produksi perikanan selama lima tahun terakhir.

Tabel 1. Produksi Perikanan Tangkap Pantai Pelabuhan Ratu Tahun 2011-2015

\begin{tabular}{lccc}
\hline No. & Tahun & $\begin{array}{c}\text { Produksi } \\
\text { (Kg) }\end{array}$ & Nilai (Rp) \\
\hline 1. & 2011 & $6,539,133$ & $120,339,550,319$ \\
2. & 2012 & $8,846,526$ & $183,439,608,741$ \\
3. & 2013 & $7,292,073$ & $213,439,504,947$ \\
4. & 2014 & $10,357,023$ & $288,233,337,400$ \\
5. & 2015 & $9,122,320$ & $225,823,087,000$ \\
\hline
\end{tabular}

Sumber: Laporan Statistik Perikanan Tangkap Tahun 2015 PPN Pelabuhan Ratu 
Meskipun penurunan ini tidak terlalu besar jumlahnya, akan tetapi dampak yang terjadi cukup besar. Terutama pada pengusaha yang menjadikan sektor perikanan sebagai ladang bisnis. Para pengusaha perikanan, seperti pembudidaya ikan contohnya yang dijadikan sebagai olahan makanan atau bahkan juragan kapal selaku pemilik kapal mengalami kerugian dari segi pendapatan dan keuntungan yang biasa mereka peroleh dan hasil tangkapan ikan menjadi menurun. Sedangkan oleh efek yang dirasakan nelayan adalah, selain pendapatan yang ikut menurun, mereka juga dituntut harus bekerja lebih keras, maka dari itu pendapatan yang para nelayan dapatkan ternyata tidak sesuai dengan tenaga yang mereka keluarkan.

\section{Tingkat Kesejahteraan Nelayan Pelabuhan Ratu}

Badan pusat statistik Jawa Barat tahun 2013 mengatakan bahwa jumlah nelayan kategori miskin jauh lebih rendah, yaitu sebanyak 17,74\% daripada keluarga yang bukan nelayan yaitu sebanyak 17, 37\%. Kriteria masyarakat kurang sejahtera yang sangat membutuhkan bantuan langsung tunai, dan keluarga nelayan yang termasuk kedalam kategori miskin sebanyak 9.6\% dan keluarga bukan nelayan yang tergolong miskin sebanyak 7.5\% (Muflikhati, 2010:4). Tingkat kesejahteraan terbagi kedalam tiga tingkatan, tinggi (High), rendah (Low), dan menengah (middle).

Dalam penelitian ini, tingkat kesejahteraan nelayan dapat dilihat yaitu dengan menggunakan 8 dari 14 kriteria rumah tangga miskin menurut Badan Pusat Statistik dan berdasarkan dengan data lapangan, yaitu sebagai berikut.

1. Luas lantai bangunan kurang dari $8 \mathrm{~m}^{2}$

Rumah yang luas lantainya kurang dari $8 \mathrm{~m}^{2}$ merupakan rumah yang bisa dikatakan tidak layak huni. Sedangkan untuk kisaran anggota keluarga nelayan biasanya rata-rata mereka berjumlah 3-6 orang dalam satu rumah. Meskipun jumlah tanggungan keluarganya cukup banyak, rumah nelayan di kawasan Pelabuhan Ratu masih bisa dikatakan layak huni dengan luas lantai $>8 \mathrm{~m}^{2}$.

2. Sumber Penghasilan Kepala Rumah Tangga dibawah Rp.600.000 perbulan

Pendapatan nelayan baik sebagai buruh maupun petani dibawah Rp.600.000 per-bulan.Pendapatan nelayan dikatakan rendah jika penghasilan selama satu bulan kurang dari Rp.600.000. Pendapatan nelayan rata-rata jika dihitung perhari memang dibawah Rp.600.000, untuk nelayan kapal kecil mereka biasa mendapatkan upah harian sebesar Rp.25.000Rp.40.000. Sedangkan untuk nelayan kapal besar, mendapat upah harian sebanyak Rp.75.000-100.000 sedangkan untuk anak buah kapal biasa mereka mendapatkan upah harian yang sama seperti nelayan kecil yaitu sebesar Rp.25.000-40.000.

3. Pendidikan Tertinggi Kepala Rumah Tangga Hanya sampai Sekolah Dasar

Secara umum tingkat pendidikan nelayan tergolong rendah, Sampai Pendidikan nelayan Pelabuhan Ratu masuk kedalam kategori rendah, dari 30 orang responden, 15 orang diantaranya hanya menempuh pendidikan sampai sekolah dasar, 12 orang tidak lulus sekolah dasar, sedangkan untuk nelayan yang menempuh pendidikan hingga tamat SMA hanya ada 3 orang.

4. Tidak memiliki tabungan dan barang yang bernilai

Nelayan di kawasan Pesisir Pantai Pelabuhan Ratu, rata-rata tidak memiliki tabungan untuk kebutuhan mereka. Ketika mendapatkan penghasilan, mereka cenderung langsung membagi pendapatan mereka untuk berbagai macam pengeluaran, termasuk pengeluaran untuk melaut, perawatan kapal dan bekal untuk melaut. 
5. Bahan bakar memasak masih menggunakan arang dan kayu bakar

Bahan bakar yang digunakan oleh para nelayan tersebut sudah memakai gas. Jarang yang masih memakai arang untuk memasak

6. Tidak ada biaya untuk berobat ke puskesmas dan rumah sakit

Beberapa nelayan dikawasan

Pelabuhan Ratu masih memilih pengobatan tradisional atau tidak berobat sama sekali karena kurangnya biaya.

7. Jenis lantai tempat tinggal terbuat dari tanah

Sebagian besar rumah dikawasan pesisir pantai Pelabuhan Ratu berlantai semen dan kayu yang sudah rusak, 60\% semen dan $40 \%$ kayu.

8. Sumber penerangan tidak memakai listrik

Untuk kriteria ini, para nelayan tersebut tidak termasuk kedalam kategori miskin, karena untuk kawasan Pelabuhan Ratu sudah memakai listrik sebagai sumber penerangan.

Tingkat kesejahteraan nelayan dibagi ke dalam 3 bagian; miskin, kaya dan menengah. Dari 30 responden yang ada, hampir 50\% nelayan kapal kecil masuk kedalam kategori miskin, sedangkan untuk nelayan kapal besar, tingkat kemiskinan yang anya berkisar $25 \%$.

Berikut merupakan nilai presentase tingkat kemiskinan nelayan kapal kecil dan nelayan kapal besar.

Tabel 2. Kategori Tingkat Kemiskinan Nelayan Pelabuhan Ratu

\begin{tabular}{llcc}
\hline No. & Kategori & $\begin{array}{c}\text { Nelayan } \\
\text { kapal besar }\end{array}$ & $\begin{array}{c}\text { Nelayan } \\
\text { kapal kecil }\end{array}$ \\
\hline 1 & Kaya & $50 \%$ & $15 \%$ \\
2 & Miskin & $25 \%$ & $50 \%$ \\
3 & Menengah & $25 \%$ & $25 \%$ \\
\hline
\end{tabular}

Sumber, Hasil Penelitian, 2017

Dari tabel 2 tersebut, dapat disimpulkan secara keseluruhan bahwa tingkat kesejahteraan nelayan kapal kecil rendah dan masuk kedalam kriteria tingkat kemiskinan ika dibandingkan dengan nelayan kapal besar.

\section{Karakteristik Nelayan Pelabuhan Ratu}

Berdasarkan observasi dan wawancara, nelayan dari luar Jawa Barat lebih banyak jumlahnya, hampir semua dari nakhkoda sampai ke anak buah kapal berasal dari luar Jawa Barat. Nelayan yang mayoritas penduduk asli dari Pelabuhan Ratu itu sendiri jumlahnya hanya sedikit. Selain berasal dari wilayah yang berbeda-beda, dalam penelitian ini karakteristik nelayan diklasifikasikan menjadi lima bagian, yaitu usia, tingkat pendidikan, jumlah tanggungan, pendapatan rumah tangga dan pengeluaran rumah tangga.

1. Usia Nelayan

Dalam penelitian ini, kisaran usia nelayan yang paling muda adalah usia 16 tahun, dan usia lanjut adalah usia 54 tahun. Dari hasil penyebaran kuesioner, jika dihitung secara menyeluruh ratarata usia nelayan di kawasan pelabuhan ratu berusia 26-40 tahun, dengan usia paling muda 16 tahun dan yang berusia 54 tahun hanya satu orang. Jika berdasarkan pada perbedaan kapal, usia nelayan kapal besar masih tergolong muda dengan rata-rata usia 16-30 tahun.

Usia nelayan kapal kecil rata-rata berusi 26-40 tahun. Adapun nelayan berusia lanjut hanya satu orang, akan tetapi meskipun sudah memasuki usia yang cukup lanjut, usia 54 tahun masih dikatakan usia yang masih produktif, karena usia produktif bagi seseorang yang bekerja baik sebagai nelayan maupun bukan sebagai nelayan dimulai sejak usia 15-64 tahun

2. Tingkat Pendidikan Nelayan

Tingkat pendidikan nelayan tergolong rendah. Rendahnya tingkat pendidikan juga dirasakan para nelayan di kawasan Pelabuhan Ratu, rata-rata pendidikan yang ditempuh hanya sampai sekolah dasar, dari 30 responden yang diambil, 15 orang diantaranya hanya tamat sekolah dasar, sedangkan yang 
tidak lulus sekolah dasar mencapai 12 orang.

Dari 30 responden yang diwawancarai hanya berjumlah 3 orang yang meneruskan sekolahnya sampai sekolah menengah atas. Rendahnya tingkat pendidikan nelayan Pelabuhan Ratu bisa disebabkan oleh dua faktor, Pertama, mereka sudah terbiasa dari kecil melaut, dan yang kedua, karena kurangnya biaya untuk melanjutkan sekolah membuat mereka memilih untuk mengikuti jejak orangtuanya melaut dan membantu meningkatkan perekonomian, meskipun terkadang pendapatan yang mereka hasilkan belum mencukupi kebutuhan keluarganya ditambah dengan statusnya hanya seorang nelayan kecil yang penghasilannya dibagi dengan juragan atau pemilik kapal.

$\begin{array}{lll}\text { 3. Jumlah Tanggungan } & \text { Keluarga } \\ \text { Nelayan } & & \\ \text { Jumlah } & \text { tanggungan keluarga }\end{array}$ nelayan Pelabuhan Ratu berkisar antara 2-6 jumlah tanggungan, 5 orang nelayan menangung 6 orang jumlah tanggungan, 5 orang nelayan berikutnya dengan jumlah tanggungan sebanyak 4 orang, sedangkan 5 nelayan lainnya belum mempunyai tanggungan,atau belum menikah, sedangkan nelayan yang lain menanggung 2-3 orang jumlah tanggungan.

4. Pendapatan Rumah Tangga Nelayan

Total pendapatan nelayan adalah seluruh penghasilan nelayan dari semua sumber pendapatan, baik sebagai nelayan maupun bukan nelayan (Kurniasari, 2016:36). Dua kategori pendapatan nelayan, nelayan kapal besar dan nelayan kapal kecil, maka dari itu pendapatan untuk masing-masing nelayan pun berbeda, nelayan kapal besar, pendapatan mereka dari melaut selama 3-6 bulan dengan sistem digaji sebesar Rp.75-100.000/hari sedangkan untuk anak buah kapal mereka digaji sebesar 25-40.000/hari itupun tergantung keuntungan pemilik kapal, jika tangkapan melewati target yang harus dicapai maka akan diberi bonus tambahan. Sedangkan pendapatan untuk nelayan kapal kecil tidak diberikan dengan sistem gaji, akan tetapi dengan upah harian atau bagi hasil dengan juragan, karena untuk kapal kecil waktu berlayar hanya berkisar 1-10 hari saja dengan pendapatan Rp.25.00040.000/hari dan untuk hitungan perbulannya bisa mencapai 1-3 juta. Berikut gambaran dari pendapatan selama per-bulan dan per-hari.

Tabel 3. Pendapatan nelayan perbulan dan perhari

\begin{tabular}{ccc}
\hline \multirow{2}{*}{ Nelayan } & \multicolumn{2}{c}{ Pendapatan } \\
\cline { 2 - 3 } Kapal besar & Pp75ari & Perbulan \\
& Rp.10000- & Rp.3.000.000 \\
ABK & Rp.25.000- & Rp. 1.200.000 \\
& Rp.40.000 & \\
Kapal kecil & Rp.25.000- & Rp.1.200.000 \\
& Rp.40.000 & \\
\hline
\end{tabular}

Sumber: Hasil penelitian,2017

Berdasarkan tabel 3 nelayan kapal besar memperoleh pendapatan jauh lebih tinggi dan berbeda jauh dengan pendapatan nelayan kapal kecil. Pendapatan nelayan kapal kecil jika dihitung perhari hanya mendapatkan Rp. 400.000 selama melaut 10 hari, mereka juga harus membagi keuntungan yang mereka dapatkan dengan juragan kapal. Sistem bagi hasil di kawasan Pelabuhan Ratu sudah sesuai dengan peraturan yang sudah ditetapkan, 25\% untuk nelayan pemilik dan $75 \%$ untuk nelayan penggarap, dengan begitu pendapatan para nelayan tersebut sudah termasuk bagi hasil dengan nelayan pemilik kapal dan nelayan penggarap.

Pendapatan Rp.400.000 dalam hitungan perhari sebenarnya belum mencukupi kebutuhan mereka apabila ditambah dengan jumlah tanggungan yang lebih dari dua orang atau bahkan lebih, tidak hanya untuk kebutuhan sehari-hari, untuk kebutuhan melaut sebenarnya belum mencukupi karena untuk kebutuhan melaut, setidaknya 
mereka harus mempunyai uang minimal Rp.1-2.000.000,- itu untuk semua keperluan operasional selama melaut.

Pendapatan nelayan kapal besar lebih besar daripada pendapatan nelayan kapal kecil, karena mereka memperoleh pendapatan dengan cara digaji oleh pemilik kapal, pendapatan para nelayan kapal berukuran diatas 5 Gross Ton tersebut sudah mencukupi untuk mereka dan keluarganya dikampung, mereka juga tidak perlu memikirkan kebutuhan melaut, itu semua sudah ditanggung oleh pemilik kapal, biasanya semua kebutuhan tersebut akan dikirim sehari sebelum mereka pergi melaut, dari mulai beras hingga ke makanan ringan semua sudah terpenuhi.

Terdapat perbedaan yang cukup jauh antara nelayan kapal kecil dengan nelayan kapal besar,baik dari segi pendapatan maupun kebutuhan operasional dan kebutuhan sehari-hari. Meskipun pendapatan nelayan kapal besar berpendapatan jauh lebih besar, akan tetapi itu semua tetap bergantung kepada keuntungan pemilik kapal dan target yang harus dicapai oleh mereka, jika mereka bisa melewati target yang seharusnya, maka mereka akan diberikan bonus tambahan oleh pemilik kapal. Lain lagi dengan nelayan kapal kecil, selain harus membagi hasil dengan juragan, mereka juga harus menjual ikan ke tempat pelelangan ikan sesuai dengan harga pasar, ikan yang mereka jual terkadang tidak sesuai dengan harga pasar, atau kadang lebih murah, semakin kecil hasil pendapatan dari menjual ikan, maka semakin sedikit pendapatan yang diperoleh dari bagi hasil dengan juragan kapal.

5. Pengeluaran Rumah Tangga Nelayan

Pengeluaran rumah tangga nelayan terbagi kedalam dua kategori yaitu, pengeluaran untuk pangan dan nonpangan, pengeluaran untuk kebutuhan melaut, biaya untuk merawat kapal dan penyusutan kapal. Pengeluaran ini dialokasikan ke dalam beberapa kebutuhan, yaitu:

a. Pengeluaran untuk Kebutuhan Sehari-Hari (Pangan \& Non Pangan)

Dari hasil penelitian, total pengeluaran pangan dan non-pangan adalah Rp. 374.000 Jika jumlah pendapatan nelayan kecil selama satu bulan Rp.1.200.000, itu berarti setengah dari pendapatan tersebut digunakan untuk kebutuhan sehari-hari. Pendapatan sebesar itu hanya cukup untuk kebutuhan rumah tangga saja, akan tetapi belum bisa mencukupi kebutuhan melaut. Nelayan kecil harus mempunyai pendapatan $\geq$ Rp.1.200.000, perbulan demi bisa mencukupi kebutuhan melaut dan kebutuhan sehariharinya. Berikut rincian pengeluaran nelayan kecil dan nelayan kapal besar setiap 1 kali pergi melaut.

Tabel 4. Biaya Operasional Melaut (Nelayan Kapal Kecil)

\begin{tabular}{lll}
\hline $\mathrm{N}$ & \multicolumn{1}{c}{$\begin{array}{c}\text { Biaya Operasional } \\
\text { o. }\end{array}$} & \multicolumn{1}{c}{ Biaya } \\
\hline 1. & Solar & Rp. 450.000 \\
2. & Oli & Rp. 600.000 \\
3. & Es Balok & Rp. 15.000/Balok \\
& Perbekalan & Rp. 225.000 \\
4. & (Makanan) & \\
& $\quad$ Jumlah & Rp. 1.290 .000 \\
\hline
\end{tabular}

Sumber: Hasil penelitian 2017

Berdasarkan tabel 4 dapat disimpulkan bahwa pengeluaran untuk melaut lebih besar dan berbeda dengan pengeluaran untuk kebutuhan seharihari, pendapatan mereka sebenarnya masih mencukupi untuk kebutuhan sehari-hari, akan tetapi belum bisa mencukupi untuk kebutuhan melaut.

Tabel 5. Biaya Operasional Melaut (Nelayan Kapal Besar)

\begin{tabular}{|c|c|c|}
\hline No. & $\begin{array}{c}\text { Biaya } \\
\text { Operasional (1 } \\
\text { kali melaut) }\end{array}$ & Biaya \\
\hline 1. & BBM & Rp.297.000 \\
\hline 2. & Air/Liter & Rp.356.000 \\
\hline 3. & Oli & Rp.12.150.000 \\
\hline 4. & $\begin{array}{l}\text { Perbekalan } \\
\text { Makanan }\end{array}$ & Rp.4.3.000.000 \\
\hline
\end{tabular}




\begin{tabular}{cl}
\hline Jumlah & Rp. \\
& 12.807 .300 .000 \\
\hline
\end{tabular}

Sumber: Hasil penelitian 2017

Berbeda dengan nelayan kapal besar, berdasarkan tabel 5 yang menunjukkan besarnya pengeluaran nelayan kapal besar untuk 1 kali melaut. Meskipun pengeluaran untuk melaut jauh lebih besar, para nelayan kapal besar tidak terlalu mengalami kesulitan mengenai kebutuhan operasional melaut, karena semua sudah di tanggung. Berikut total perbedaan besarnya pengeluaran nelayan kapal kecil dan kapal besar.

b. Pengeluaran untuk Perawatan Kapal dan Penyusutan Kapal

Kebutuhan untuk pemeliharaan kapal juga sama pentingnya, demi menunjang aktivitas melaut. Berikut rincian biaya untuk 1 kali perawatan kapal.

Tabel 6. Pengeluaran perawatan kapal

\begin{tabular}{ccc}
\hline No. & $\begin{array}{c}\text { Pengeluaran } \\
\text { untuk 1 kali } \\
\text { perawatan kapal }\end{array}$ & $\begin{array}{c}\text { Jumlah } \\
\text { pengeluaran }\end{array}$ \\
\hline 1. & Perawatan Kapal & Rp.2.000.000 \\
2. & Mesin Kapal & Rp.3.000.000 \\
3. & Alat Tangkap & Rp. 1.500 .000 \\
Total Pengeluaran & Rp.6.500.000
\end{tabular}

Sumber: Hasil Penelitian,2017

Berdasarkan tabel 6 total biaya yang dibutuhkan untuk setiap 1 kali perawatan kapal sebesar Rp.6.500.000, besarnya biaya tersebut akan jauh lebih besar lagi jumlahnya jika ditambah dengan adanya biaya penyusutan pada alat tangkap, berikut biaya yang harus dikeluarkan untuk setiap alat tangkap.

Dengan bertambahnya biaya penyusutan dan biaya perawatan kapal, maka dari itu, yang saat ini dibutuhkan oleh para nelayan adalah modal tambahan, terutama bagi nelayan kapal kecil. Kebutuhan nelayan yang terakhir adalah kebutuhan alat tangkap perunit, kisaran harga alat tangkap tergantung pada jenis alat tangkapnya, alat tangkap paling murah adalah harga yang kisarannya dari Rp. 50.000-100.000, dan yang paling mahal yang harganya bisa mencapai lebih dari Rp.10.000.000.

Besarnya jumlah modal yang dibutuhkan oleh nelayan kapal kecil untuk kebutuhan melaut sama dengan modal yang dibutuhkan oleh nelayan kapal besar yang bekal operasionalnya sangat besar untuk persediaan selama 36 bulan melaut. Untuk mengetahui besarnya kebutuhan, dan produk pembiayaan seperti apa yang sesuai untuk kebutuhan nelayan maka ada beberapa analisis dalam penelitian ini, diantaranya analisis pendapatan, analisis pengeluaran rumah tangga, analisis kebutuhan modal dan yang terakhir pendekatan dalam analisis produk pembiayaan.

\section{Analisis Pendapatan Nelayan}

Analisis ini dilakukan untuk mengetahui pendapatan mereka lebih besar saat mereka melaut atau saat melakukan pekerjaan sampingan. Setelah dilakukan perhitungan dengan cara membagi hasil tangkapan dengan cara membagi hasil tangkapan selama satu bulan dan menghitung besaran jumlah pendapatan dari melaut dijumlahkan dengan pendapatan dari pekerjaan sampingan.

Berdasarkan hasil dari perhitungan tersebut, dapat disimpulkan bahwa pendapatan dari pekerjaan sampingan lebih besar dari pendapatan saat melaut.

\section{Analisis Pengeluaran Rumah Tangga Nelayan}

Analisis perhitungan pengeluaran tersebut dihitung berdasarkan keseluruhan jumlah pengeluaran pangan baik yang pokok maupun tidak, untuk diambil kesimpulan apakah lebih besar pengeluaran bahan pangan pokok atau pengeluaran non-pangan.

Total jumlah pengeluaran pokok, dihitung dengan cara menghitung jumlah keseluruhan pengeluaran pangan dibagi 
dengan jumlah tanggungan keluarga. Sedangkan jumlah pengeluaran non pangan dihitung dengan cara yang sama yaitu membagi total keseluruhan pengeluaran non pangan dibagi dengan jumlah tanggungan keluarga.

Hasil perhitungan tersebut menunjukkan bahwa pengeluaran untuk kebutuhan non pangan lebih besar dari kebutuhan pangan dengan jumlah tanggungan yang sama. Jika jumlah tanggungannya berbeda maka total pengeluaran akan jauh lebih besar dan perbedaanya cukup jauh, dari perhitungan diatas dapat disimpulkan, semakin banyak jumlah tanggungannya semakin besar pengeluarannya, akan tetapi jika jumlah tanggungan keluarga tersebut jauh lebih sedikit maka pengeluaran juga akan semakin sedikit jumlahnya. Dan sifat konsumtif mereka jelas sangat terlihat dari lebih banyaknya jumlah pengeluaran untuk kebutuhan yang lain, dibandingkan untuk kebutuhan sehari-harinya.

\section{Analisis Kebutuhan Modal}

Kebutuhan yang paling membutuhkan modal yang banyak adalah kebutuhan untuk melaut, mereka harus mempunyai modal \pm Rp.2.000.000 untuk biaya operasional setiap satu kali pergi melaut, seperti kebutuhan solar, dan es balok, BBM, dan bekal konsumsi. Modal yang mereka dapatkan untuk memenuhi kebutuhan sehari- hari dan kebutuhan melaut mereka dapatkan dari modal sendiri, mereka tidak mau meminjam ke bank karena prosesnya yang lama dan persyaratannya cukup sulit bagi mereka.

Besarnya modal yang harus mereka punya adalah sekitar Rp.1.000.0005.000 .000 untuk biaya operasional setiap 1 kali pergi melaut dan biaya perawatan kapal, sisanya untuk kebutuhan mereka. Modal yang habis untuk membeli solar, sekitar Rp.450.000 untuk 90 liter solar, sedangkan untuk biaya pemeliharaan alat tangkap bisa mencapai Rp.2.000.000,-. Jika dihitung secara lebih rinci lagi, maka total dari keseluruhan pendapatan yang mereka dapatkan hanya sebesar Rp.300.000.

Berikut rincian perhitungan secara keseluruhan.

10 hari pergi melaut x Rp.1.200.000 $=$ Rp.12.000.000 x 10 orang nelayan -( Rp.347.000 + Rp.450.000) $=$ Rp.677.000

Jadi dapat disimpulkan total bersih pendapatan nelayan atau penghasilan nelayan dari kecil yang mereka dapatkan diluar untuk pengeluaran pangan non pangan dan kebutuhan melaut, dengan satu kapal berisikan 10 orang nelayan hanya mempunyai uang sebesar Rp.677.000.

\section{Pendekatan dalam analisis produk pembiayaan}

Pendekatan dalam analisis ini dilakukan dengan beberapa tahap diantaranya:

a. Aspek keuangan hal pertama yang dilihat oleh seorang analis pembiayaan pada bank syariah, karena aspek ini merupakan hal yang akan menentukan jumlah modal dan penilaian untuk kemampuan nasabah terutama dalam membayar pembiayaan.

b. Kebutuhan mendasar bagi nelayan terbagi kedalam beberapa bagian, yaitu, kebutuhan akan alat transportasi melaut, alat tangkap, dan kebutuhan pemeliharaan alat-alat dan yang terakhir kebutuhan modal.

\section{Analisis pendapatan}

Pendapatan yang dihasilkan selama ini jauh lebih banyak dihasilkan dari pekerjaan sampingan, bukan dari hasil melaut, akan tetapi meskipun lebih besar jumlahnya, penghasilan yang mereka dapatkan tersebut belum bisa mencukupi untuk kebutuhan sehari-hari dan kebutuhan melaut.

\section{Analisis Kesesuaian Antara Produk dan Kemampuan Nelayan}

Analisis pembiayaan dilakukan oleh bagian account officer dalam suatu 
lembaga keuangan yang tugasnya menganalisis setiap pengajuan pembiayaan.Untuk itu sebelum memberikan pembiayaan, bank syariah memberikan beberapa syarat yang harus dipenuhi, syarat ini dikenal dengan prinsip 5 C yaitu. Character, capacity, collateral, dan condition of Economy. Diantara kelima prinsip tersebut, character merupakan prinsip yang harus dipenuhi, karena jika prinsip ini tidak dipatuhi maka permohonan pembiayaan ditolak.Selain character, collateral juga menjadi salah satu prinsip yang paling penting dan harus dipenuhi.

Bank BRI syariah mempunyai produk pembiayaan yang dapat membantu meringankan permasalahan para nelayan di wilayah tersebut, ada 3 produk pembiayaan yang diberikan kepada nelayan, yaitu:

a) Pembiayaan menggunakan akad jual beli murabahah, plafon pembiayaan ini berkisar Rp.75-200.000.00, adapun syarat yang harus dipenuhi adalah dengan cara memberikan agunan dengan jangka waktu pembayaran selama 6-60 bulan. Pembiayaan ini disebut dengan produk IB 200.

b) Pembiayaan dengan akad jual beli murabahah, plafon pembiayaan ini berkisar Rp.5-75.000.000.00, adapun syarat yang harus dipenuhi adalah dengan cara memberikan agunan dengan jangka waktu pembayaran selama 6-60 bulan. Pembiayaan ini disebut dengan pembiayaan IB 75 . Pembiayaan ini biasanya diberikan untuk nelayan pemilik untuk melengkapi kurangnya modal dan untuk melengkapi peralatan melaut seperti umpan, es balok dan bahan bakar minyak.

c) Pembiayaan menggunakan akad jual beli murabahah tanpa adanya agunan sebagai syarat dan jaminan dengan angsuran dalam jangka waktu 12-48 bulan. pembiayaan ini disebut dengan pembiayaan KUR Mikro IB. Pembiayaan ini diberikan untuk nelayan kapal kecil atau anak buah kapal, plafon pembiayaan ini berkisar antara Rp.5-25.000.000 dengan jangka waktu angsuran selama 3 tahun, pembiayaan ini biasanya dikhususkan untuk pembiayaan modal kerja.

Angsuran pembiayaan ini kurang dari Rp.500.000 setiap bulan, masih bisa dipenuhi oleh nelayan kapal kecil, akan tetapi meskipun angsurannya tidak terlalu memberatkan nelayan, banyak nelayan yang kurang berminat karena meskipun tidak ada jaminan yang sulit, akan tetapi mereka harus memilik usaha produktif, seperti usaha warung misalnya. Sedangkan rata-rata mereka hanya akan membuka usaha warung atau berdagang jika sedang musim paceklik dan hanya menjadikannya sebagai pekerjaan sampingan.

Dari ketiga produk pembiayaan tersebut, pembiayaan KUR IB dengan menggunakan akad murabahah yang sesuai untuk kebutuhan nelayan, selain karena plafon yang tidak terlalu besar, angsuran yang kecil, tidak adanya jaminan yang dijadikan sebagai syarat untuk mengajukan pembiayaan juga tidak terlalu menyulitkan bagi nelayan, terutama nelayan kapal kecil dan para anak buah kapal.

Analisa Lanjut Untuk Desain Produk yang Sesuai dengan Kebutuhan Nelayan

Analisa lanjut mengenai desain produk ini dibuat untuk menganalisis kesesuaian pembiayaan yang diberikan oleh bank syariah. Metode ABC (Activity Based Coasting). Metode ini bisa diterapkan dalam desain produk melalui beberapa tahap, yaitu:

a) Cost Driver atau objek pembiayaan yang berbentuk jasa. Bisa berbentuk biaya secara tidak langsung (Overhead Cost) biaya secara tidak langsung bisa berupa modal 
tambahan untuk kebutuhan nelayan yang diberikan oleh bank syariah.

b) Biaya yang harus dikeluarkan oleh bank syariah untuk meminimalisir risiko kecelakaan selama melaut, bisa melalui jasa asuransi atau pengelolaan manajemen risiko yang ada di bank syariah tersebut.

c) Cost Driver atau pemicu munculnya biaya, pemicu munculnya biaya yang akan dialokasikan untuk kebutuhan operasional. Pemicu munculnya biaya tersebut adalah karena adanya kebutuhan sehari-hari seperti kebutuhan pangan dan non-pangan, yang memunculkan biaya lain yaitu biaya operasional melaut, pemeliharaan atau perawatan kapal, dan munculnya biaya penyusutan alat tangkap.

d) Biaya yang dikeluarkan oleh bank untuk fasilitas tertentu seperti pembelian kapal atau pembuatan kapal atau penyewaan kapal. biaya ini disebut Facility Sustaining level.

e) Biaya yang dikeluarkan oleh bank syariah untuk kebutuhan lainnya sesuai dengan syarat dan ketentuan yang sudah diterapkan dan dengan menerapkan salah satu prinsip 5'C yaitu Condition of Economy dari nasabah atau nelayan yang akan mengajukan pembiayaan.

Ada dua permasalahan yang menyebabkan bank syariah tidak memberikan pembiayaan kepada nelayan. Yang pertama yaitu, karena bank syariah tidak mau mengambil risiko adanya kredit macet saat nelayan membayar angsuran. Dan yang kedua, jika dilihat dari salah satu prinsip 5'C yaitu Condition Of Economy, nelayan akan kesulitan melunasi pembiayaan mereka nantinya karena pendapatan mereka selama 1 bulan untuk nelayan kapal kecil hanya sebesar Rp.1.000.000 masih kurang cukup untuk melunasi pembiayaan.
Dengan pendapatan sebesar itu setiap bulannya, mereka harus menyisihkan sebagian pendapatan mereka sebesar Rp.500.000 untuk angsuran ke bank, maka dengan sisa pendapatan yang mereka punya mereka harus membaginya lagi untuk kebutuhan sehari-hari dan melaut. Sedangkan kebutuhan melaut mereka tidak sedikit jumlahnya oleh karena itu bank tidak mau mengambil risiko kredit macet atau gagal bayar karena kondisi nelayan yang seperti ini. Sedangkan jika dilihat dari sisi nelayan adalah, nelayan tidak mau mencoba mengajukan pembiayaan ke bank syariah karena adanya jaminan dan syarat yang mereka rasa terlalu rumit, jaminan yang harus mereka berikan biasanya terkait dengan surat-surat kepemilikan rumah dan juga adanya syarat yang mengharuskan mereka mempunyai usaha produktif terlebih dahulu, demi bisa mengajukan pembiayaan.

Jika mereka bisa memenuhi syarat yang bank syariah butuhkan, misalnya membuat usaha produktif, mereka akan mengalami kesulitan di persyaratan lainnya seperti memberikan jaminan lain, dan sebaliknya jika mereka bisa memberikan jaminan tersebut, ternyata mereka tidak memiliki usaha produktif sebagai syarat untuk mengajukan pembiayaan, ada juga nelayan yang mengalami kesulitan di kedua syarat tersebut.

Murabahah merupakan akad yang bisa diterapkan untuk para nelayan, terutama pembiayaan untuk modal kerja. Akan tetapi adanya jaminan dalam akad tersebut membuat kesulitan nelayan semakin bertambah. Untuk itu diperlukan pembiayaan yang tidak menyulitkan masing-masing pihak baik nelayan maupun bank syariah, pembiayaan ini bisa dalam bentuk jaminan, seperti kafalah contohnya, kafalah adalah jaminan yang diberikan oleh penanggung jawab kepada pihak 
kedua atau yang ditanggung. Jaminan ini bisa berupa asuransi syariah.

Murabahah menggunakan jaminan asuransi syariah bisa diterapkan oleh bank syariah sebagai salah satu alternatif untuk pembiayaan bagi nelayan dan dapat dikaji kedalam penelitian selanjutnya apakah pembiayaan dengan murabahah bil kafalah ini sesuai untuk memenuhi kebutuhan nelayan.

\section{KESIMPULAN DAN IMPLIKASI}

Berdasarkan hasil penelitian, kesimpulan mengenai kondisi perekonomian nelayan kawasan pesisir pantai Pelabuhan Ratu masih tergolong kurang sejahtera, pendapatan dan pengeluaran masih tergolong rendah dan belum bisa memenuhi kebutuhan mereka yang jauh lebih besar, terutama kebutuhan untuk melaut. Pendapatan mereka memang masih bisa mencukupi kebutuhan sehari-hari, akan tetapi belum bisa memenuhi kebutuhan lainnya seperti kebutuhan untuk melaut, pendidikan dan kesehatan.

Produk pembiayaan yang sesuai untuk kebutuhan nelayan adalah. Produk pembiayaan KUR mikro IB yang sudah diterapkan oleh bank BRI syariah cabang pembantu Pelabuhan Ratu dengan menggunakan akad jual beli murabahah bil kafalah.

\section{DAFTAR PUSTAKA}

\section{Jurnal}

Amin. 2016. Pengaruh Citra Perusahaan dan Citra Pemakai terhadap Keputusan Pembelian Jasa Perbankan Syariah. Jurnal RelasiVol. 12, No 1.

Agam, Alpharesy. 2012. Analisis Pendapatan dan Pola Pengeluaran Rumah Tangga Nelayan Buruh di Wilayah Pesisir Kampak Kabupaten Bangka Barat. Jurnal Perikanan dan Kelautan Vol. 3 No.1, 15.

\section{Buku}

Arifin, Ansar. 2014.Mata Rantai Kemiskinan Nelayan dan Strategi Pengentasannya Kajian Ilmu Sosial dan Politik. Bandung: Orbit Media.

Rustardi. 2015. Laporan Statistik Perikanan Tangkap. Pelabuhan Ratu: Direktorat Jendral Perikanan Tangkap Kementerian Kelautan dan Perikanan.

\section{Skripsi}

Afandi, Anif. 2016. Akad Istishna Pararel Sebagai Alat untuk Merealisasikan Misi Negara Kemaritiman Universitas Indonesia.

Ariani. 2014. Kumpulan Skripsi Sarjana,Perkembangan Sosial Ekonomi Masyarakat Nelayan. Universitas Jember 